\title{
Genomic Fingerprinting by Microsatellite-primed PCR: A Critical Evaluation
}

\author{
Kurt Weising, ${ }^{1,2}$ Ross G. Atkinson, ${ }^{3}$ and Richard C. Gardner ${ }^{1}$
}

\begin{abstract}
${ }^{1}$ Centre for Gene Technology, School of Biological Sciences, University of Auckland, Auckland, New Zealand; ${ }^{2}$ Plant Molecular Biology Group, Biozentrum, Johann Wolfgang Goethe University, D-60439 Frankfurt, Germany; ${ }^{3}$ The Horticulture and Food Research Institute of New Zealand Ltd., Mt. Albert, Auckland, New Zealand
\end{abstract}

\begin{abstract}
Single PCR primers complementary to microsatellite repeats were used to amplify genomic DNA samples from various plant species, as well as from human, yeast, and Escherichia coll DNA. Most primers generated distinct amplification products, resulting in fingerprint-like banding patterns after agarose gel electrophoresis and ethidium bromide staining. These fingerprints allowed distinction among different plant taxa at an interspecific as well as intraspecific level. Unexpectedly, some of the primers produced bands with the $E$. coli template DNA as well. A detailed examination of the influence of PCR conditions, especially the annealing temperature, on the quality of banding patterns suggested that the majority of bands were generated by mismatch priming in a way similar to random amplified polymorphic DNAs (RAPDs).
\end{abstract}

n recent years numerous strategies have been developed to visualize DNA polymorphisms by PCR. One approach involves the amplification of anonymous DNA fragments using arbitrary GC-rich primers, the separation of the amplified fragments on agarose or polyacrylamide gels, and their detection by ethidium bromide or silver staining. This technique, known as random amplified polymorphic DNA (RAPD) analysis, ${ }^{(1,2)}$ arbitrarily primed PCR (APPCR), ${ }^{(3)}$ or DNA amplification fingerprinting (DAF) ${ }^{(4)}$ is fast and easy to perform, requires no prior sequence information, and is therefore immediately applicable to any species of interest. Disadvantages, however, include the dominant segregation behavior of RAPD bands, which does not allow discrimination between homo- and heterozygous states, ${ }^{(2)}$ as well as the high sensitivity of the banding patterns to slight changes in reaction conditions, causing reproducibility problems. $^{(5-7)}$

A second approach makes use of the presence of high copy numbers of interspersed repeats in many eukaryotic genomes. In a technique termed Alu-PCR, primers complementary to members of the human-specific Alu family of repeats were exploited to amplify unique DNA sequences between adjacent Alu repeats. ${ }^{(8)}$ PCR fragments generated by Alu-PCR were often found to be polymorphic ("alumorphs"), and inherited in a Mendelian fashion. (9) The principle of inter-repeat PCR has been adapted to other kinds of interspersed repeats found in humans as well as in other organisms. ${ }^{(10,11)}$ In contrast to RAPDs, more stringent annealing conditions can be applied. However, sequence information is needed to generate repeat-specific primers.

Still another increasingly popular strategy of generating PCR-based molecular markers is targeted at microsatellites, that is, tandem repeats of short sequence motifs (mainly 2-4 nucleotides), which are ubiquitous constituents of eukaryotic DNA. ${ }^{(12,13)}$ Individual microsatellites often show a "variable number of tandem repeats." Such polymorphism can be visualized by PCR with a pair of locus-specific flanking primers, electrophoresis of the amplification products, and detection by autoradiography, staining, or fluorescence. Microsatellites represent almost optimal markers: They are polymorphic within populations, highly abundant and evenly dispersed throughout eukaryotic genomes, inherited in a codominant fashion, and fast and easy to type. ${ }^{(14-18)}$ However, a major disadvantage is that sequence information is needed to design flanking primers. Whereas a few informative primer pairs may be derived from data base entries, the usual strategy is to screen genomic libraries with appropriate probes, followed by sequencing of positive clones. The requirement for cloning and sequencing makes the generation of PCRbased microsatellite markers time-consuming and expensive, limiting the large-scale use of this approach to a few important species. ${ }^{(15-18)}$

Recently, a PCR strategy was introduced that combines elements of AluPCR, microsatellite, and RAPD analysis. ${ }^{(19,20)}$ In this approach microsatellite- 
complementary oligonucleotides serve as single primers. If inversely repeated microsatellites are located within an amplifiable distance of one another, the inter-repeat sequences are amplified. Separation of the resulting amplification products on agarose gels followed by ethidium bromide staining allowed differentiation of strains and serotypes of the human fungal pathogen Cryptococcus neoformans, ${ }^{(19)}$ and identification of a new whitefly species. ${ }^{(20)}$ The principle of this technique was subsequently applied to some other fungi ${ }^{(21)}$ and to one higher plant species, Phragmites australis. ${ }^{(22)}$ In a related approach, $5^{\prime}$ - or $3^{\prime}$-anchored CA repeats served as single PCR primers, and the amplification products were separated on polyacrylamide gels. ${ }^{(23)}$ Complex, fingerprint-like patterns were obtained that revealed interspecific as well as intraspecific polymorphisms from a variety of eukaryotic taxa. ${ }^{(23)}$

Meyer and colleagues ${ }^{(19,21)}$ stressed that microsatellite-primed PCR combined some advantages of RAPD analysis (i.e., no need for sequence information), and of "standard" microsatellite analysis (i.e., use of high-stringency annealing conditions, leading to more reproducible banding patterns). To our knowledge, however, the latter prediction has not been tested rigorously so far. In the present paper, we used 19 different unanchored oligonucleotides (representing di-, tri-, and tetranucleotide repeats) to (1) test the applicability of microsatellite-primed PCR for different areas of genetic analysis, and (2) to monitor the sensitivity of the technique to various reaction conditions.

\section{MATERIALS AND METHODS Plant and DNA Material}

Leaf material from different accessions of Actinidia chinensis, A. arguta, A. setosa, $A$. chrysantha, and $A$. deliciosa was obtained from Hort Research Orchards, Te Puke, New Zealand. Tomato (Lycopersicon esculentum) plants were grown at the University of Auckland. Genomic DNA samples were kindly supplied by D. Love (human DNA), C. MacDiarmid (yeast DNA), S. Ledger (apple and Arabidopsis DNA) (all from the University of Auckland, New Zealand), and M. Connett (Pinus radiata DNA) (Tasman Forestry, Rotorua, New Zealand). Escherichia coli DNA was purchased commercially.

\section{DNA Isolation}

Genomic DNA was isolated from $A C$ tinidia and tomato leaves according to a modified cetyltrimethylammonium bromide (CTAB) procedure. ${ }^{(24)}$ DNA concentrations were determined electrophoretically using known amounts of $\lambda$ DNA as standards. ${ }^{(25)}$ For PCR, DNA samples were diluted to $10 \mathrm{ng} / \mathrm{\mu l}$.

\section{Microsatellite-primed PCR}

Oligonucleotide primers complementary to microsatellite repeats (Table 1) were purchased commercially and diluted to $10 \mathrm{pM} / \mu \mathrm{l}$ in TE buffer. Unless stated otherwise, PCR was performed in $25-\mu$ l reaction volumes containing 20 $\mathrm{mM}$ Tris- $\mathrm{HCl}(\mathrm{pH} 8.4) ; 50 \mathrm{mM} \mathrm{KCl} ; 1.8$ $\mathrm{mM} \mathrm{MgCl}_{2}, 0.2 \mathrm{~mm}$ of each dATP, dCTP, dGTP, and dTTP; $0.4 \mu \mathrm{M}$ primer $(=10$ pM/reaction); $0.06 \mathrm{U} / \mu \mathrm{l}$ of Taq DNA polymerase (GIBCO-BRL); and 50 ng of template DNA. In some experiments, $3 \mathrm{~mm}$ magnesium acetate was included. ${ }^{(19,21)}$ Reactions were overlayed with two drops of mineral oil. The temperature regime suggested by Meyer et al. ${ }^{(19,21)}$ was followed: After initial denaturation $\left(94^{\circ} \mathrm{C}, 2\right.$ min), PCR was run for 40 cycles each consisting of a $94^{\circ} \mathrm{C}$ denaturing step (20 sec), an annealing step at various temperatures depending on the experiment (60 sec), and a $72^{\circ} \mathrm{C}$ elongation step (20 sec) in a Techne PHC-3 thermocycler. At the end of the run, a final extension period was included $\left(72^{\circ} \mathrm{C}\right.$ for $\left.6 \mathrm{~min}\right)$. Samples were separated on $1.4 \%$ agarose gels in TBE buffer ${ }^{(25)}$ and stained with ethidium bromide.

\section{RAPD Analysis}

RAPD analysis with arbitrary 10-mer primers (Operon, Alameda, CA) was per- formed by a modification of the method of $\mathrm{Yu}$ and Pauls (28) (G. Gill, pers. comm.). Reaction mixtures were as described for microsatellite-primed PCR except for the concentrations of $\mathrm{MgCl}_{2}$ (2.5 $\mathrm{mm}$ ) and Taq DNA polymerase $(0.025 \mathrm{U} / \mu \mathrm{l})$. PCR was run for 38 cycles, each consisting of a $94^{\circ} \mathrm{C}$ denaturing step (5 sec), a $35^{\circ} \mathrm{C}$ annealing step (30 sec), and a $72^{\circ} \mathrm{C}$ elongation step (20 sec) in a Techne PHC-3 thermocycler. At the end of the run, a final extension period was included $\left(72^{\circ} \mathrm{C}\right.$ for $\left.6 \mathrm{~min}\right)$. In some experiments, the same amplification conditions as detailed for microsatelliteprimed PCR were used. Samples were separated on agarose gels as described above.

\section{Cloning and Sequencing of PCR Products}

Total PCR products of selected primer/ template combinations were cloned as described. $^{(29)}$ In short, PCR products were purified through a Magic PCR column (Promega Laboratories), bluntended with E.coli DNA polymerase I Klenow fragment, phosphorylated with polynucleotide kinase, and ligated into the EcoRV site of a dephosphorylated pBluescript vector (Stratagene). Ligation products were transformed into heat shock-competent DH5 $\alpha$ cells, and positive clones identified by blue/white screening. Plasmids were isolated according to standard procedures ${ }^{(25)}$ and sequenced by the dideoxynucleotide chain termination method ${ }^{(30)}$ using an Applied Biosystems 373A DNA sequencer.

\section{Hybridization Experiments}

In some experiments, agarose gels with

TABLE 1 Primers Used

\begin{tabular}{|c|c|c|c|c|c|}
\hline $\begin{array}{l}\text { Basic motif } \\
\text { Dinucleotide } \\
\text { Trinucleotide }\end{array}$ & \multicolumn{4}{|c|}{ Primer sequence } & $\begin{array}{l}\begin{array}{l}\text { Melting } \\
\text { temperature }\left({ }^{\circ} \mathrm{C}\right)\end{array} \\
48\end{array}$ \\
\hline $\begin{array}{l}\text { Dinucleotide } \\
\text { Trinucleotide }\end{array}$ & $\begin{array}{l}(\mathrm{GT})_{8}, \\
(\mathrm{TAA})_{5} \\
(\mathrm{GTG})_{5}, \\
(\mathrm{CAA})_{5}, \\
(\mathrm{GACA})_{4}, \\
(\mathrm{GATA})_{4}, \\
(\mathrm{TAAA})_{4}\end{array}$ & $\begin{array}{l}(\mathrm{GA})_{8} \\
(\mathrm{CAG})_{5}, \\
(\mathrm{CAT})_{5} \\
(\mathrm{GGAT})_{4}, \\
(\mathrm{GAAT})_{4},\end{array}$ & $\begin{array}{l}(\mathrm{TCC})_{5,} \\
(\mathrm{CTA})_{5 \prime} \\
(\mathrm{CCTA})_{4}, \\
(\mathrm{GTTA})_{4}\end{array}$ & $\begin{array}{l}(\mathrm{CGA})_{5} \\
(\mathrm{GAA})_{5} \\
(\mathrm{CATA})_{4}\end{array}$ & $\begin{array}{l}48 \\
30 \\
50 \\
40 \\
48 \\
40 \\
32\end{array}$ \\
\hline
\end{tabular}

The melting temperature was calculated according to the Wallace rule $\left(2^{\circ} \mathrm{C}\right.$ for each AT pair, $4^{\circ} \mathrm{C}$ for each GC pair). ${ }^{26,27}$ See text for annealing temperatures used in the PCR experiments. 
PCR products were blotted onto nylon membranes (Hybond Nfp, Amersham) and hybridized to ${ }^{32} \mathrm{P}$-endlabeled oligonucleotide probes. Probe labeling with polynucleotide kinase, blotting, hybridization, washing, and autoradiography were essentially done as described. ${ }^{(31)}$

\section{RESULTS}

\section{Analysis of PCR Products from Di-, Tri-, and Tetranucleotide Repeat Primers}

PCR with unanchored, microsatellitecomplementary oligonucleotides as single primers was reported to produce PCR fingerprints from genomic DNA of two whitefly, several fungal, and one plant species so far. ${ }^{(19-22)}$ To examine the general applicability of this method, we tested a range of 19 different oligonucleotides representing di-, tri-, and tetranucleotide repeats as PCR primers for the analysis of genomic DNA from different organisms. We also examined in some detail the influence of PCR conditions on the banding patterns obtained. Primers are listed in Table 1, together with the melting temperature deduced from the "Wallace rule," that is, $4^{\circ} \mathrm{C}$ for every GC pair, and $2{ }^{\circ} \mathrm{C}$ for every AT pair. ${ }^{(26,27)}$

We first tested the full set of primers with tomato and $A$. chinensis template DNA (Fig. 1). PCR conditions were as described in Materials and Methods, except for the presence of $1.4 \mathrm{~mm}$ instead of 1.8 $\mathrm{mM} \mathrm{MgCl}{ }_{2}$. Two different annealing temperatures were used: $50^{\circ} \mathrm{C}$ for primers with $50 \%$ and more $\mathrm{GC}$, and $40^{\circ} \mathrm{C}$ for primers with $<50 \%$ GC. We observed three different types of amplification product patterns (Fig. 1). First, distinct PCR fingerprints were produced by all GC-rich trinucleotide and all tetranucleotide repeats [except for (TAAA) ${ }_{4}$, see below]. These primers usually yielded $1-20$ bands in a molecular mass range of $0.3-2$ $\mathrm{kb}$. Second, all dinucleotide repeats and some AT-rich (i.e., $>66 \%$ AT) trinucleotide repeats resulted in a smear rather than discrete bands. Third, primers with $100 \%$ AT content did not yield any products under the chosen PCR conditions, possibly because of premature dissociation of the primer/template complex (data not shown). No amplification products occurred in the absence of template DNA (negative control). Because a given primer produced fairly consistent types of amplification products with

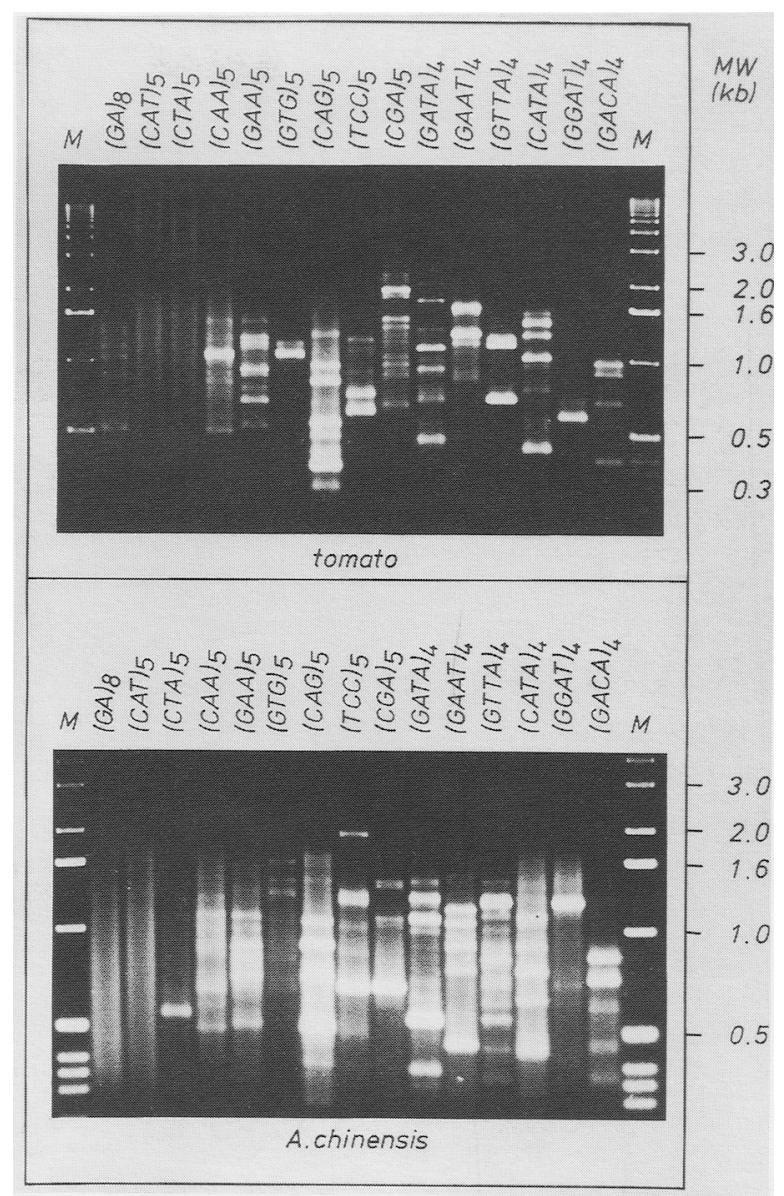

FIGURE 1 PCR products obtained by different microsatellite-complementary oligonucleotides as single primers using tomato and $A$. chinensis DNA as a template. Annealing temperatures were $40^{\circ} \mathrm{C}$ for primers with $<50 \% \mathrm{GC}$, and $50^{\circ} \mathrm{C}$ for primers with $50 \% \mathrm{GC}$ and more. (Lane $\mathrm{M}$ ) Molecular weight marker: 1-kb ladder (GIBCO-BRL).

both investigated templates, primer sequence and length appear to be the main determinants of the type of amplification products obtained.

\section{Microsatellite Repeats are not Enriched in Microsatellite-primed PCR Products}

Different types of microsatellites are frequently found intermingled with each other. $^{(15-18)}$ Therefore, we reasoned that DNA fragments amplified by microsatellite-primed PCR might harbor additional simple repeats between the primer binding sites. If this were the case, microsatellite-primed PCR could serve as an easy method for the identification of additional microsatellites and their locusspecific flanking regions. We took two approaches to test this assumption. First, we cloned and sequenced selected microsatellite-primed PCR products ampli- fied from the tomato and $A$. chinensis genomes. However, the sequence of eight fragments obtained from different primers did not reveal any internal repeat structure in a total of $\sim 2000$ nucleotides. Second, we hybridized Southern blots of microsatellite-primed PCR products to selected, radiolabeled oligonucleotides complementary to the same, or a different, motif. Because microsatellites are not expected to be enriched in RAPD fragments, Southern blots of RAPD products generated by arbitrary 10-mer primers served as controls. Using (GTTA) ${ }_{4}$ as a probe, only (GTTA) $)_{4}$-amplified fragments hybridized, that is, there were no (GTTA) ${ }_{n}$ repeats present in PCR products from other primers. The same was true for other 3- and 4-base repeats used as probes. In contrast, rehybridization of the blots to dinucleotide repeat probes $(\mathrm{GT})_{8}$ or $(\mathrm{GA})_{8}$ resulted in strong and distinct signals in almost all lanes (data not 
shown). As these signals did not correspond to the ethidium bromide staining patterns, they most likely reflect minor amplification products carrying microsatellite repeats. Bands with similar intensities were, however, also observed in control experiments hybridizing $(\mathrm{GT})_{8}$ or $(\mathrm{GA})_{8}$ to a blot with RAPD products generated from operon primers. Taken together, the sequencing and hybridization results indicated that dinucleotide and other repeats are not particularly enriched in the amplification products generated by microsatellite-primed PCR. Hybridization of microsatellite-complementary probes to Southern blots of RAPDs may nevertheless serve as an additional source for polymorphic markers (T. Richardson, R.C. Gardner and K. Weising, in prep.).

\section{Microsatellite-primed PCR Detects Interspecific and Intraspecific Variation in Actinidia species}

Next, we investigated whether microsatellite-primed PCR allowed detection of interspecific and/or intraspecific polymorphisms in different species, varieties, and accessions of the genus Actinidia. The same set of accessions was also examined with arbitrary 10-mer primers using the RAPD conditions of $\mathrm{Yu}$ and Pauls. ${ }^{(28)}$ Results obtained with (GTTA) and the operon primer $A Q-5$ are shown in Figure 2, A and B, respectively. With both techniques and all tested primers, a considerable number of intraspecific and interspecific polymorphisms were observed. As expected, the similarity of banding patterns was higher within a species than between two species. The level of polymorphism detected by RAPD versus microsatellite primers appeared similar. Operon primers had the tendency to produce a larger number of bands, which were, however, harder to score. These results suggest that microsatellite-primed PCR can be used for relatedness studies in a similar way to RAPDs. ${ }^{(32,33)}$

To test the usefulness of microsatellite-primed PCR for linkage and mapping studies, we analyzed the parents of an intraspecific cross between two $A$. chinensis genotypes. Only 4 of 12 tested primers detected differences between the parents. Of these, (GATA) ${ }_{4}$ was used to screen $10 F_{1}$ progeny for segregation of the polymorphisms (Fig. 2C). Whereas the four main bands were

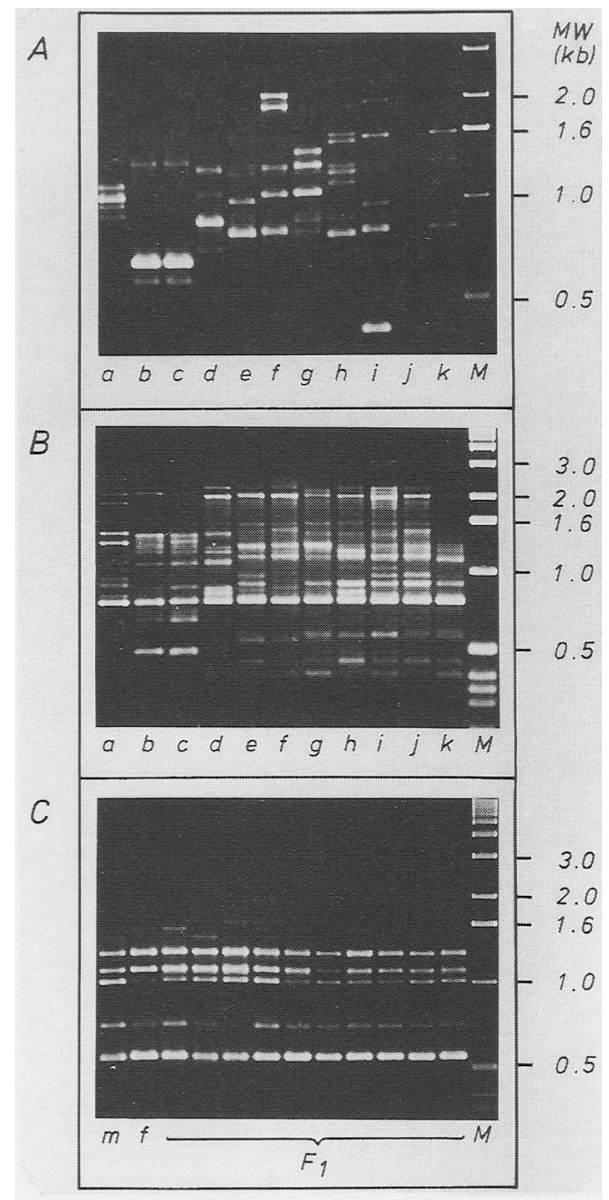

FIGURE 2 Interspecific and intraspecific polymorphism detected by microsatellite-primed PCR. (A) PCR products obtained from different accessions of (lane $a$ ) $A$. arguta, (lanes $b, c$ ) $A$. chrysantha, (lane $d$ ) A. setosa, (lanes $e-g$ ) A. deliciosa, and (lanes $h-k$ ) $A$. chinensis DNA using (GTTA) ${ }_{4}$ as a single primer. (B) RAPD analysis of the same templates using OP-AQ5 (operon) as a single primer. $(C)$ PCR products obtained from the parents ( $m$, male; $f$, female) and the $F_{1}$ progeny of a cross between two $A$. chinensis accessions using (GATA) ${ }_{4}$ as a single primer. Annealing temperatures were $40^{\circ} \mathrm{C}$ in $A$ and $C$, and $35^{\circ} \mathrm{C}$ in $B$. (Lane $\mathrm{M}$ ) Molecular weight marker: 1-kb ladder (GIBCO-BRL).

monomorphic between the parents, some minor bands were polymorphic and segregated in the progeny. Thus, the overall informativeness of microsatellite-primed PCR-generated markers in this particular cross was low.

\section{Microsatellite-primed PCR Works with Eukaryotic and Prokaryotic Templates}

Next we, tested the applicability of the technique to a variety of species from different kingdoms, including E.coli, yeast, human, and several plant species. The results obtained with the primers $(\text { GATA })_{4}$ and (CATA $)_{4}$ are shown in Figure 3 . All primers that yielded distinct banding patterns in $A$. chinensis and tomato did so in all other eukaryotic species examined. Some of the primers also generated PCR products with $E$. coli DNA, though the number of products was usually smaller and the pattern less complex than observed with arbitrary 10-mer primers (see Fig. 5, below). This result was somewhat surprising, because microsatellite repeats typically are not found in prokaryotic genomes. A data base search showed that none of the microsatellite motifs used as primers was perfectly present in the $E$. coli genome. Instead, we consistently found a minimum of from one to four mismatches. As the data base covers most of the $E$. coli genome, and because amplification requires the presence of two closely linked, inverted copies of the repeat, it is likely that the bands obtained from $E$. coli resulted from mismatches between primer and template. This would mean that at least a subset of the bands obtained by microsatellite-primed PCR resembles RAPD bands rather than true intermicrosatellite repeats.

\section{Influence of Primer, Template, and Magnesium Concentration}

In RAPD analysis, reaction conditions have a considerable impact on the quality and reproducibility of results. ${ }^{(5-7)}$ Meyer and co-workers emphasized that microsatellite-primed PCR would be more reproducible than RAPD analysis because of the higher stringency of annealing. ${ }^{(19)}$ To test for this, we examined in some detail the influence of primer, template, and $\mathrm{Mg}^{2+}$ concentration, as well as of annealing temperature (see below) on the reproducibility of banding patterns obtained by microsatelliteprimed PCR. We found the banding patterns to be affected by all of these parameters (Figs. 4 and 5). Template concentration had the smallest influence. Thus, patterns were fairly stable between $\sim 100 \mathrm{pg}$ and $500 \mathrm{ng}$ in the tomato/(GATA) $)_{4}$ combination (Fig. 4D), and even down to $10 \mathrm{pg}$ in the $A$. chinensis/(CAG) $)_{5}$ combination (not shown). Hence, the concentration "window," where identical patterns are observed, 


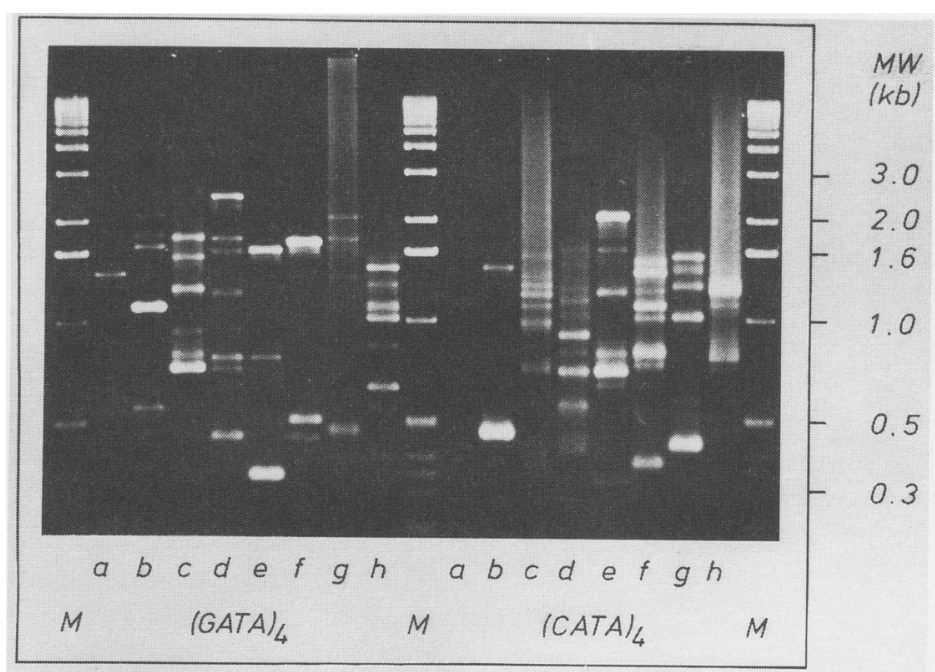

FIGURE 3 Microsatellite-primed PCR in different kingdoms. PCR products obtained from different organisms using (GATA) ${ }_{4}$ (left) or (CATA) ${ }_{4}$ (right) as single primers. Template DNA (50 ng/ sample) was derived from $E$. coli (lane $a$ ), yeast (lane $b$ ), human (lane $c$ ), $P$. radiata (lane $d$ ), Arabidopsis thaliana (lane $e$ ), apple (lane $f$ ), tomato (lane $g$ ), and $A$. deliciosa (lane $h$ ). The annealing temperature was $40^{\circ} \mathrm{C}$. (Lane M) Molecular weight marker: 1-kb ladder (GIBCO-BRL).

appears to be somewhat larger than that usually reported for RAPDs.

The influence of both primer and $\mathrm{Mg}^{2+}$ concentration was more pronounced. Generally, smaller bands became stronger, and larger bands faded off with increasing concentrations of $\mathrm{Mg}^{2+}$ (Fig. 4A) or primer (Fig. 4B,C). Similar effects are usually observed in
RAPDs. ${ }^{(7)}$ No amplification products were detected with 1 pM of primer per 25 $\mu l$ reaction (i.e., a concentration of 40 $\mathrm{nM})$, and with both high (10 mM) and low $(0.5 \mathrm{~mm})$ concentrations of $\mathrm{Mg}^{2+}$. The inclusion of magnesium acetate, as recommended by Meyer et al., ${ }^{(19,21)}$ did not result in a higher reproducibility of banding patterns but simply contributed

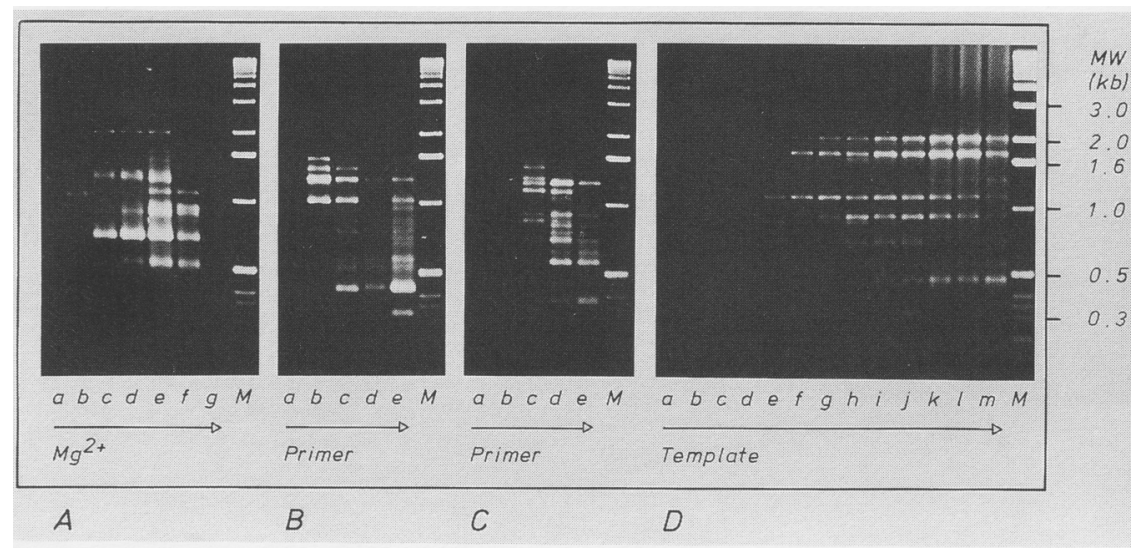

FIGURE 4 Influence of reaction conditions on microsatellite-primed PCR products from different primer/template combinations. $(A) \mathrm{Mg}^{2+}$ concentration: PCR products obtained from $A$. chinensis DNA in the presence of $0.5 \mathrm{~mm}$ (lane $a$ ), $1.0 \mathrm{mM}$ (lane $b$ ), $1.4 \mathrm{~mm}$ (lane $c$ ), $1.8 \mathrm{~mm}$ (lane $d$ ), 2.4 $\mathrm{mM}$ (lane $e$ ), $5.0 \mathrm{~mm}$ (lane $f$ ), and $10.0 \mathrm{~mm}$ (lane $g$ ) $\mathrm{MgCl}_{2}$ using (TCC) 5 as a single primer. The annealing temperature was $50^{\circ} \mathrm{C}$. $(B, C)$ Primer concentration: PCR products obtained from tomato $(B)$ and $A$. chinensis DNA $(C)$ using 1 pM (lane $a$ ), 5 pM (lane $b$ ), 10 pM (lane $c$ ), 20 pM (lane $d)$, and $50 \mathrm{pm}$ (lane $e$ ) of $(\mathrm{CATA})_{4}(B)$ and (GTTA) $)_{4}(C)$ as a single primer (per 25 - $\mu$ l reaction). The annealing temperature was $40^{\circ} \mathrm{C}$. $(D)$ Template concentration: PCR products obtained from different amounts of tomato DNA using (GATA) ${ }_{4}$ as a single primer: No template (lane $a$ ), $0.5 \mathrm{pg}$ (lane $b$ ), $5 \mathrm{pg}$ (lane $c$ ), $10 \mathrm{pg}$ (lane $d$ ), $50 \mathrm{pg}$ (lane $e$ ), $100 \mathrm{pg}$ (lane $f$ ), $500 \mathrm{pg}$ (lane $g$ ) $1 \mathrm{ng}$ (lane $h$ ), $5 \mathrm{ng}$ (lane $i$ ), $10 \mathrm{ng}$ (lane $j$ ) $50 \mathrm{ng}$ (lane $k$ ) $100 \mathrm{ng}$ (lane $l$ ) and $500 \mathrm{ng}$ (lane $m$ ) of template. The annealing temperature was $40^{\circ} \mathrm{C}$. (Lane M) Molecular weight marker: 1-kb ladder (GIBCO-BRL). to the magnesium effect. All subsequent experiments were performed using 1.8 $\mathrm{mM} \mathrm{MgCl}_{2}, 10 \mathrm{pm}$ of primer, and $50 \mathrm{ng}$ of template DNA per reaction.

\section{Influence of Annealing Temperature}

The results obtained so far suggest that at least some of the microsatellite-primed PCR products actually resemble RAPD bands. The question arose whether there were also "true" intermicrosatellite repeats among the amplification products. To test this, we amplified identical template/primer combinations at various annealing temperatures. We expected that bands derived from mismatch priming would disappear at high temperatures, while bands derived from $100 \%$ match priming would persist. GC-rich RAPD primers (operon 10-mers) were included as a negative control (no repeats); cloned fragments with pure (GTTA) ${ }_{4}$ or (GACA) sequences at the ends (see above) as positive controls (100\% match). Annealing was performed at $37^{\circ} \mathrm{C}, 40^{\circ} \mathrm{C}, 43^{\circ} \mathrm{C}, 46^{\circ} \mathrm{C}$, and $50^{\circ} \mathrm{C}$ for AT-rich microsatellite and 10 -mer primers, and at $50^{\circ} \mathrm{C}, 53^{\circ} \mathrm{C}, 56^{\circ} \mathrm{C}$, $60^{\circ} \mathrm{C}, 64^{\circ} \mathrm{C}$, and $68^{\circ} \mathrm{C}$ for GC-rich microsatellite primers. The results obtained for the (GACA) $)_{4}$ primer are shown in Figure 5. To our surprise, annealing temperatures that exceeded the Wallace rule $e^{(26,27)}$ by $>10^{\circ} \mathrm{C}$ not only produced a band of the expected size with the positive controls but also still yielded amplification products with genomic DNA. The banding patterns were nevertheless different from those produced at lower annealing temperatures. With all primer/template combinations, raising the annealing temperature led to the gradual disappearance of some bands, whereas other bands became stronger (Fig. 5). Dinucleotide repeats still produced a smeared pattern of amplification products at high annealing temperatures (not shown).

Two lines of evidence suggested that high annealing temperatures alone do not guarantee $100 \%$ matching of primer and template. First, four bands amplified from the $E$. coli genome by the (GACA) primer "survived" at $64^{\circ} \mathrm{C}$ annealing temperature (Fig. 5), that is, the highest temperature at which the $100 \%$ matching "positive control" plasmid was still amplified. Similar results were obtained with other primers (not shown). Because the presence of true (GACA) ${ }_{4}$ and other microsatellite target sequences in the $E$. 


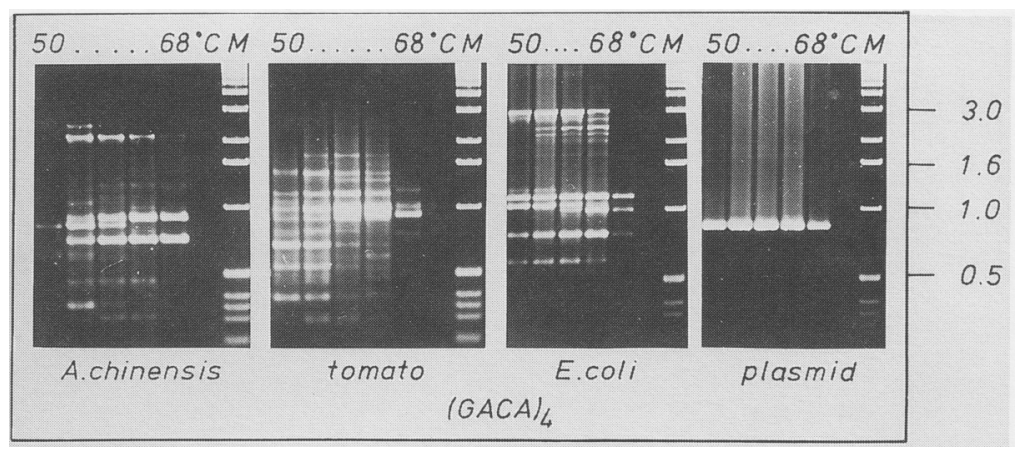

FIGURE 5 Influence of annealing temperature on microsatellite-primed PCR products obtained from the (GACA) ${ }_{4}$ primer and different templates (genomic DNA from $A$. chinensis, tomato, or $E$. coli). A cloned PCR product carrying (GACA) ${ }_{4}$ repeats at both ends was included as positive control ("plasmid"). Identical primer/template combinations are arranged in groups with increasing annealing temperatures (each from left to right: $50^{\circ} \mathrm{C}, 53^{\circ} \mathrm{C}, 56^{\circ} \mathrm{C}, 60^{\circ} \mathrm{C}, 64^{\circ} \mathrm{C}$, and $68^{\circ} \mathrm{C}$ ). (Lane M) Molecular weight marker: 1-kb ladder (GIBCO-BRL).

coli genome is highly unlikely (see above), mismatch-primed target sites must have been amplified successfully even at $64^{\circ} \mathrm{C}$. Second, repeating the magnesium and primer concentration experiments at high annealing temperature [i.e., $64^{\circ} \mathrm{C}$ for $(\mathrm{GACA})_{4},(\mathrm{CGA})_{4}$, and $(\mathrm{TCC})_{5}$ ] still showed the concentration dependence of banding patterns, with smaller bands predominating at higher primer and/or magnesium concentrations (not shown).

\section{DISCUSSION}

Our results confirm and extend previous observations that PCR primed by microsatellites ${ }^{(19-23)}$ or other kinds of repeats ${ }^{(9,11,34)}$ can detect genetic polymorphisms in eukaryotic taxa. Distinct, polymorphic banding patterns were produced by most primers consisting of tetranucleotide or GC-rich trinucleotide repeats. All dinucleotide and some trinucleotide repeats, however, generated a smear with a few superimposed bands, probably as a consequence of the high number of putative primer target sites. Anchoring of primers as suggested by Zietkiewicz and co-workers ${ }^{(23)}$ overcomes this limitation but does not seem necessary for most tri- and tetranucleotide repeat primers.

In our hands, the technique of microsatellite-primed PCR, as orginally proposed by Meyer et al. ${ }^{(19)}$ and Perring et al., ${ }^{(20)}$ resembles RAPD analysis more closely than anticipated previously. Thus, primer and magnesium concentration as well as the annealing temperature had a considerable influence on the quality of banding patterns. Moreover, the generation of PCR products with E.coli template DNA, which probably is devoid of microsatellites, suggested that mismatch priming may occur quite frequently. With all primer/template combinations, increasing the annealing temperature resulted in the gradual disappearance of some bands while other bands became stronger. We interpret these results as follows. Bands amplified by single microsatellite primers can be generated basically by two mechanisms. First, RAPD-like bands result from mismatch priming during the first cycles. Extensive primer/template mismatches are known to be tolerated by Taq polymerase, provided that a few bases at the $3^{\prime}$ end match perfectly. ${ }^{(35-38)}$ Once extension from a mismatched primer occurs, the products of subsequent cycles fully match with the primer at both ends. Depending on the extent of initial mismatch, such RAPD-like bands gradually disappear at elevated annealing temperatures. Second, true interrepeat bands (which may actually represent only a minor fraction) result from specific binding of the primer to a complementary microsatellite repeat. If "unanchored" primers are used, binding to a microsatellite may occur initially in different registers. However, repeated internal priming during subsequent cycles will shorten the amplicons successively, resulting in end products carrying a single primer motif at each end. Such bands are still generated by use of annealing temperatures that considerably exceed those calculated by the Wallace rule. ${ }^{(26,27)}$ They may even become stron- ger, because "better" targets are favored at higher temperatures. However, our results obtained with E.coli template DNA suggest that even the highest possible annealing temperature does not guarantee a $100 \%$ match.

In summary, microsatellite-primed PCR is an easy and fast technique to visualize polymorphisms at an interspecific and intraspecific level. However, in our hands, the technique appears to be quite similar to RAPDs, especially in terms of its susceptibility to slight changes in reaction conditions. An advantage is the versatility of the primers, because they can be used for at least three purposes: (1) as hybridization probes for oligonucleotide fingerprinting; ${ }^{(31)}$ (2) as hybridization probes for library screening; ${ }^{(18)}$ and (3) as single primers for microsatellite-primed PCR. ${ }^{(19-23)}$ It remains to be tested whether alternative strategies to enhance PCR specificity such as preamplification heating, ${ }^{(39)}$ or the inclusion of formamide, ${ }^{(40)}$ tetramethylammonium chloride, ${ }^{(41)}$ or spermidine ${ }^{(42)}$ in the reaction will restrict amplification to "true" inter-microsatellite repeats.

\section{ACKNOWLEDGMENTS}

K.W. was supported by a FAZIT fellowship (Frankfurt am Main) and the Deutsche Forschungsgemeinschaft (DFG). The research was supported by a grant from the New Zealand Foundation for Research, Science, and Technology (93 HRT 07 249).

\section{REFERENCES}

1. Williams, J.G.K., A.R. Kubelik, K.J. Livak, J.A. Rafalski, and S.V. Tingey. 1990. DNA polymorphisms amplified by arbitrary primers are useful as genetic markers. $\mathrm{Nu}$ cleic Acids Res. 18: 6531-6535.

2. Williams, J.G.K., M.K. Hanafey, J.A. Rafalski, and S.V. Tingey. 1993. Genetic analysis using random amplifed polymorphic DNA markers. Methods Enzymol. 218: 704-740.

3. Welsh, J. and M. McClelland. 1990. Fingerprinting genomes using PCR with arbitrary primers. Nucleic Acids Res. 18: 7213-7218.

4. Caetano-Anollés, G., B.J. Bassam, and P. Gresshoff. 1991. High resolution DNA amplification fingerprinting using very short arbitrary oligonucleotide primers. BioTechnology 9: 553-557. 
5. Penner, G.A., A. Bush, R. Wise, W. Kim, L. Domier, K. Kasha, A. Laroche, G. Scoles, S.J. Molnar, and G. Fedak. 1993. Reproducibility of random amplified polymorphic DNA (RAPD) analysis among laboratories. PCR Methods Applic. 2: 341-345.

6. Muralidharan, K. and E.K. Wakeland. 1993. Concentration of primer and template qualitatively affects products in random-amplified polymorphic DNA PCR. BioTechniques 14: 362-364.

7. Ellsworth, D.L., K.D. Rittenhouse, and R.L. Honeycutt. 1993. Artifactual variation in randomly amplified polymorphic DNA banding patterns. BioTechniques 14: 214-216.

8. Nelson, D.L., S.A. Ledbetter, L. Corbo, M.F.Victoria, R. Ramirez-Solis, T.D. Webster, D.H. Ledbetter, and C.T. Caskey. 1989. Alu polymerase chain reaction: A method for rapid isolation of human-specific sequences from complex DNA sources. Proc. Natl Acad. Sci. 86: 66866690.

9. Sinnett, D., J.-M. Deragon, L.R. Simard, and D. Labuda. 1990. Alumorphs - Human DNA polymorphisms detected by polymerase chain reaction using Alu-specific primers. Genomics 7: 331-334.

10. Ledbetter, S.A., D.L. Nelson, S.T. Warren, and D.H. Ledbetter. 1990. Rapid isolation of DNA probes within specific chromosomal regions by interspersed repetitive sequence polymerase chain reaction. $G e-$ nomics 6: 475-481.

11. Versalovic, J., T. Koeuth, and J.R. Lupski. 1991. Distribution of repetitive DNA sequences in eubacteria and application to fingerprinting of bacterial genomes. $\mathrm{Nu}$ cleic Acids Res. 19: 6823-6831.

12. Beckmann, J.S. and J.L. Weber. 1992. Survey of human and rat microsatellites. $\mathrm{Ge}$ nomics 12: 627-631.

13. Wang, Z., J.L. Weber, G. Zhong, and S.D. Tanksley. 1994. Survey of plant short tandem repeats. Theor. Appl. Genet. 88: 1-6.

14. Hearne, C.M., S. Ghosh, and J.A. Todd. 1992. Microsatellites for linkage analysis of genetic traits. Trends Genet. 8: 288-294.

15. Weissenbach, J., G. Gyapay, C. Dib, A. Vignal, J. Morisette, P. Millasseau, G. Vaysseix, and M. Lathrop. 1992. A secondgeneration linkage map of the human genome. Nature 359: 794-801.

16. Dietrich, W., J.C. Miller, R.G. Steen, M. Merchant, D. Damron, R. Nahf, A. Gross, D.C. Joyce, M. Wessel, R.D. Dredge, A. Marquis, L.D. Stein, N. Goodman, D.C. Page, and E.S. Lander. 1994. A genetic map of the mouse with 4,006 simple sequence length polymorphisms. Nature Genet. 7: 220-225.

17. Rohrer, G.A., L.J. Alexander, J.W. Keele, T.P. Smith, and C.W. Beattie. 1994. A microsatellite linkage map of the porcine genome. Genetics 136: 231-245.

18. Wu, K.-S. and S.D. Tanksley. 1993. Abun- dance, polymorphism, and genetic mapping of microsatellites in rice. Mol. \& Gen. Genet. 241: 225-235.

19. Meyer, W., T.G. Mitchell, E.Z. Freedman, and R. Vilgalys. 1993. Hybridization probes for conventional DNA fingerprinting used as single primers in the polymerase chain reaction to distinguish strains of Cryptococcus neoformans. J. Clin. Microbiol. 31: 2274-2280.

20. Perring, T.M., A.D. Cooper, R.J. Rodriguez, C.A. Farrar, and T.S. Bellows. 1993. Identification of a whitefly species by genomic and behavioral studies. Science 259: 74-77.

21. Meyer, W., E. Lieckfeldt, K. Kuhls, E.Z. Freedman, T. Börner, and T.G. Mitchell. 1993. DNA- and PCR-fingerprinting in fungi. In DNA fingerprinting: State of the Science (ed. S.D.J. Pena, R. Chakraborty, J.T. Epplen, and A.J. Jeffreys), pp. 311-320. Birkhäuser Verlag, Basel, Switzerland.

22. Neuhaus, D., H. Kühl, J.-G. Kohl, P. Dörferl, and T. Börner. 1993. Investigation on the genetic diversity of Phragmites stands using genomic fingerprinting. Aquat. Bot. 45: 357-364.

23. Zietkiewicz, E., A. Rafalski, and D. Labuda. 1994. Genome fingerprinting by simple sequence repeat (SSR)-anchored polymerase chain reaction amplification. $\mathrm{Ge}$ nomics 20: 176-183.

24. Janssen, B.-J. and R. Gardner. 1993. The use of transient GUS expression to develop an Agrobacterium-mediated gene transfer system for kiwifruit. Plant Cell Rep. 13: 28-31.

25. Sambrook. J., E.F. Fritsch, and T. Maniatis. 1989. Molecular cloning: A laboratory manual. Cold Spring Harbor Laboratory Press, Cold Spring Harbor, New York.

26. Miyada, C.G. and R.B. Wallace. 1987. Oligonucleotide hybridization techniques. Methods Enzymol. 154: 94-107.

27. Innis, M.A. and D.H. Gelfand. 1990. Optimization of PCRs. In PCR protocols. A guide to methods and applications (eds. M.A. Innis, D.H. Gelfand, J.J. Sninsky, and T.J. White), pp. 3-12. Academic Press, San Diego, CA.

28. Yu, K. and K.P. Pauls. 1992. Optimization of the PCR program for RAPD analysis. Nucleic Acids Res. 20: 2606.

29. Atkinson, R.G., G. Cipriani, D.J. Whittaker, and R.C. Gardner. 1995. An allopolyploid origin for kiwifruit (Actinidia deliciosa var. deliciosa). Theor. Appl. Genet. (in press).

30. Sanger, F., S. Nicklen, and A.R. Coulson. 1977. DNA sequencing with chain-terminating inhibitors. Proc. Natl. Acad. Sci. 74: 5463-5467.

31. Weising, K., B. Beyermann, J. Ramser, and G. Kahl. 1991. Plant DNA fingerprinting with radioactive and digoxigenated oligonucleotide probes complementary to sim- ple repetitive DNA sequences. Electrophoresis 12: 159-169.

32. Halward, T., T. Stalker, E. LaRue, and G. Kochert. 1992. Use of single primer DNA amplifications in genetic studies of peanut (Arachis hypogaea L.). Plant Mol. Biol. 18: 315-325.

33. Kazan, K., J.M. Manners, and D.F. Cameron. 1993. Genetic relationships and variation in the Stylosanthes guianenesis species complex assessed by random amplified polymorphic DNA. Genome 36: $43-49$.

34. Heath, D.D., G.K. Iwama, and R.H. Devlin. 1993. PCR primed with the VNTR core sequences yields species specific patterns and hypervariable probes. Nucleic Acids Res. 21: 5782-5785.

35. Sommer, R. and D. Tautz. 1989. Minimal homology requirements for PCR primers. Nucleic Acids Res. 17: 6749.

36. Kwok, S., D.E. Kellogg, N. McKinney, D. Spasic, L. Goda, C. Levenson, and J.J. Sninsky. 1990. Effects of primer-template mismatches on the polymerase chain reaction: Human immunodeficiency virus type 1 model studies. Nucleic Acids Res. 18: 999-1005.

37. Parker, J.D., P.S. Rabinovitch, and G.C. Burmer. 1991. Targeted gene walking polymerase chain reaction. Nucleic Acids Res. 19: 3055-3060.

38. Huang, M.-M., N. Arnheim, and M.F. Goodman. 1992. Extension of base mispairs by Taq DNA polymerase: Implications for single nucleotide discrimination in PCR. Nucleic Acids Res. 20: 4567-4573.

39. D'Aquila, R.T., L.J. Bechtel, J.A. Videler, J.J. Eron, P. Gorczyca, and J.C. Kaplan. 1991. Maximizing sensitivity and specificity of PCR by preamplification heating. Nucleic Acids Res. 19: 3749.

40. Sarkar, G., S. Kapelner, and S.S. Sommer. 1990. Formamide can dramatically improve the specificity of PCR. Nucleic Acids Res. 18: 7465 .

41. Hung, T., K. Mak, and K. Fong. 1990. A specificity enhancer for polymerase chain reaction. Nucleic Acids Res. 18: 4953.

42. Wan, C.-Y. and T.A. Wilkins. 1993. Spermidine facilitates PCR amplification of target DNA. PCR Methods Applic. 3: 208210 .

Received October 28, 1994; accepted in revised form January 31, 1995. 


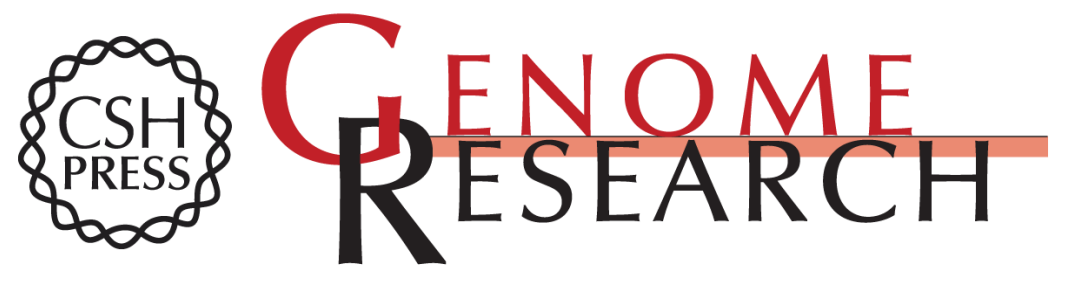

\section{Genomic fingerprinting by microsatellite-primed PCR: a critical evaluation.}

K Weising, R G Atkinson and R C Gardner

Genome Res. 1995 4: 249-255

References This article cites 38 articles, 5 of which can be accessed free at: http://genome.cshlp.org/content/4/5/249.full.html\#ref-list-1

License

Email Alerting

Receive free email alerts when new articles cite this article - sign up in the box at the Service top right corner of the article or click here.

\section{Affordable, Accurate Sequencing.}

To subscribe to Genome Research go to: https://genome.cshlp.org/subscriptions 